\title{
Effects of Raw Materials on Vermicompost Qualities
}

\section{Rahman A'ali, ${ }^{1}$ Mehrdad Jafarpour, ${ }^{1}$ Elahe Kazemi, ${ }^{1}$ and Mohammad Pessarakli ${ }^{2}$}

\author{
${ }^{1}$ Department of Horticultural Science, Agriculture and Natural Faculty, Isfahan (Khorasgan) \\ Branch, Islamic Azad University, Isfahan, Iran \\ ${ }^{2}$ School of Plant Sciences, College of Agriculture and Life Sciences, The University of Arizona
}

Address Correspondence to Mohammad Pessarakli: pessarak@email.arizona.edu

\begin{abstract}
Overuse of the chemical compounds and toxic elements leads to problems and transmission of contaminants and pollutants to humans and other living organisms. One of the industries' byproducts of the agriculture sector is production of various composts from the organic raw materials that the best type of which is so - called Vermicompost. In this study, effects of raw materials on qualitative and quantitative characteristics of Vermicompost are discussed. To do so, sheep manure, pomegranate peels, spent mushroom compost either singly or double, triple or fourfold chopped corn, sugar beet pulp and sawdust were used. This research project was conducted in a completely randomized design experiment with 23 treatments with 3 replications. Results revealed that various bed combinations exert different effects on Vermicompost quality such that, the Vermicomposting process led to a significant decrease in electrical conductivity
\end{abstract}




\section{ACCEPTED MANUSCRIPT}

(EC) and a significant increase in $\mathrm{pH}$ in most of the culture (seed) beds. Also, the levels of Nitrogen, Phosphorous and Potassium in most treatments increased following completion of the vermicomposting process. As a result, this process can be introduced as an organic fertilizer with complete nutrients for improving chemical characteristics of agricultural wastes to usable fertilizers.

Keywords: Spent mushroom compost, Eisenia foetida, pomegranate peel, sheep manure 


\section{INTRODUCTION}

Nowadays, irrational, overuse, and long-term consumption of chemical fertilizers is one of the concerns and problems of the world resulting to nothing but gradual degradation of soil quality, lower crop quality, disturbance of the ecosystem natural balance, and spread of environmental pollutions. One of the approaches for improving growth of plants, is application of organic fertilizers, the use of which being considered as an important step towards environment protection and human health and one of the most effective management procedures for protecting the soil quality at a desirable level (Tohidinejad et al., 2011). Among the organic fertilizers, Vermicompost has been proven to be one of the best ones which is produced via non thermophilic decomposition of organic materials through activity of a particular species of earthworm in combination with that of fungi and actinomycete bacteria. The result of this process is production of such products being odorless, light, like peat with high porosity, aeration, drainage, high water retention capacity, modified $\mathrm{pH}$, low electrical conductivity (EC), high cation exchange capacity (CEC), and high microbial activity (Manna et al., 2003; Sharma et al. 2005).

In addition, Vermicompost contains all the nutrients and high absorbable concentration of elements such as Nitrogen, Phosphorous, Potassium, Vitamins and Various enzymes with the potential of soil conditioning being absorbable by the plants. In addition, it reduces the environmental hazards due to organic wastes accelerate their recycling to the nature as consumable fertilizer and can be an appropriate substitute for the chemical fertilizers in 


\section{ACCEPTED MANUSCRIPT}

agriculture and horticulture (Tognetti et al. 2005; Atiyeh et al., 2002). Considering the fact that a huge portion of agricultural crops concerning all the farming, orchard and forage crops are produced through high expenditures, due to various reasons are wasted in the production to consumption cycle, this has led to many environmental and economic problems in the country. Recently, researchers have decided that by finding appropriate approaches to make use of the inconsumable organic and waste materials so that, in addition to reducing the adverse environmental effects, effective steps are taken towards control and management of the agricultural wastes. Evidently, nutritional value of the produced Vermicompost to a great extent depends on the type and nature of the raw materials used in the vermicompost processes, therefore appropriate nutritional sources for the worm, in addition to the most suitable mixture percentage of various nutrients can play a considerable role in the growth rate, reproduction and nutrition of the worm and finally produce a high quality and desirable Vermicompost (Maboeta and Van Rensburg, 2003). Also sugarbeet waste (Khalfi et al., 2005), municipal wastewater sludge (Parvaresh et al., 2005), animal waste (Alidadi et al., 2007), domestic waste (Yousefi et al., 2008), chicken manure (Petmuenwai. 2013) and cow manure (Chattopadhyay, 2012) have been studied as well. Therefore this research project was conducted with the objective of studying the various beds such as sheep manure, pomegranate peels, and spent mushroom compost, in single form and in double, triple or four-fold combinations with chopped corn, sugar beet pulp and sawdust for producing Vermicompost. Furthermore, the effect of type of raw materials on the process of Vermicompost production was investigated. Regarding the present study, it seems that some of the wastes used in this research have not been used for producing Vermicompost so far, especially, in regards to the importance of primary substrate effect on

\section{ACCEPTED MANUSCRIPT 4}




\section{ACCEPTED MANUSCRIPT}

Vermicompost production with a high quality and acceptable characteristics, study of type of raw materials on this process seems necessary.

\section{MATERIALS AND METHODS}

\section{Selection of the Organic Wastes}

Organic wastes used in this research included sheep manure, pomegranate peels (Size of pieces: 0.5 to $1 \mathrm{~cm}$ ), spent mushroom compost, as single item or in double, triple and four-fold combination (at equal ratios) with chopped corn, sugar beet pulp and sawdust.

\section{Selection of the Earthworm Species}

To perform the Vermicompost process, the Eisenia foetida earthworm species was used.

\section{Bed Preparation for Performing the Vermicompost Process}

Based on the dry weight, $10 \mathrm{~kg}$ of each substrate was poured in boxes with sizes of $50 \times 30 \times 25$ $\mathrm{cm}$ for performing the Vermicompost process. Studied treatments passed the primary composting stage in order to soften the bed materials, removing the bad odors due to production of volatile organic substances, exclusion of toxic gases like ammonia due to primary decomposition and provision of aerobic conditions. During this period, bed materials in various treatments were 


\section{ACCEPTED MANUSCRIPT}

ransacked and to control activity of the microorganism, the compost temperatures at various depths were measured by a thermometer.

Introduction of the Earthworms to the Beds and the Provision of the Environmental Conditions

Mature earth worms in the amount of $250 \mathrm{~g}(25 \mathrm{~g} / \mathrm{kg})$, were collected from the primary bed and added to each of the beds (Federico et al., 2007). All treatments were kept under cover with a $25^{\circ} \mathrm{C}$ temperature. In order to determine the appropriate time for adding worms, 10 worms at several occasions and at one - week intervals were added to the beds and their viability was examined. Beds' humidity was $70 \%$, temperature 13 to $22{ }^{\circ} \mathrm{C}$ and $\mathrm{pH}$ was about 6.8 to 7.2 . These values were reported as optimum condition for the activity of the earthworms (Sherman, 2003; Ghaisari, et al., 2009; Sharma et al. 2005).

\section{Study of Some of the Characteristics of the Beds Before and After Vermicompost Process}

The $\mathrm{pH}$ level was assessed by $\mathrm{pH}$-meter, Model 262 and electric conductivity by Ohm EC-meter, Model 664. Absorbable phosphorous was assessed by Sherwood Spectrophotometer, Model Sectra 320, in 860 nanometer wavelength, absorbable potassium by flame photometer, and Nitrogen level was assessed by the automatic Kjeldahl device, Model 3200 (Garg et al., 2006).

\section{Statistical Analysis}


This research project was conducted in a completely randomized design experiment with 23 treatments and 3 replications. Data analysis was performed via SAS software (SAS Inc., Cary, NC). In order to compare Vermicompost processes between various treatments, Duncan Multiple Range test and to compare the prior and Post - Vermicomposting processes, paired samples $\mathrm{T}$ test were used.

\section{RESULTS}

\section{Effects of Various Beds on the Electrical Conductivity (EC) Prior and After Vermicomposting Process}

The results of the data analysis of variance revealed that the effect of raw materials on EC prior and post - vermicomposting process was significant at 0.001 probability level. Comparison of the mean EC prior and post - composting process revealed the highest and the lowest salinity in pomegranate peel + sawdust and sheep manure + corn to be $11.52 \mathrm{dS} / \mathrm{m}$ and that of sheep

manure + pomegranate peel to be $2.45 \mathrm{dS} / \mathrm{m}$, respectively. Following the Vermicomposting process performance, the sheep manure + pomegranate peel + spent mushroom compost + corn compared with other beds, showed the highest EC. Based on the results of the T-test, Vermicomposting of culture beds led to their significant decrease of EC (Table 1).

The pH Level in Various Beds Before and After Vermicomposting Process 
The results of the analysis of variance revealed that, effects of the raw materials on $\mathrm{pH}$ in both times before and after Vermicomposting were significant at the 0.001 probability level. Results of the means comparison indicated that the sheep manure + pomegranate peel + sugar beet pulp bed with a $\mathrm{pH}$ of 7.97 and the pomegranate peel + sugar beet pulp with a $\mathrm{pH}$ of 7.98 , respectively, had the highest $\mathrm{pH}$ among the various beds before and after composting times. The lowest $\mathrm{pH}$ before the Vermicomposting process was that of the pomegranate + corn bed (3.67) and the spent mushroom compost bed (7.22) following vermicomposting Based on the T-test results, Vermicomposting process led to a significant increase in $\mathrm{pH}$ in the majority of the beds (Table 2).

\section{Nitrogen Level in Various Beds Before and After Vermicomposting Process}

The results of the analysis variance showed that, the effects of the raw materials on the amount of Nitrogen prior to and post - composting were significant at 0.001 probability level. Also, comparison of the mean Nitrogen levels in various beds showed that before the Vermicomposting process, the highest and the lowest Nitrogen levels in the sheep manure + spent mushroom compost + corn and in the spent mushroom compost + sugar beet +

pomegranate peels beds were $1.77 \%$ and $0.74 \%$ respectively. Following the Vermicomposting process, the highest and the lowest Nitrogen levels were observed in the sheep manure + sugar beet pulp and the spent mushroom compost + sugar beet pulp beds $(2.10 \%$ and $1.23 \%)$, respectively. Based on the T-test results, performing the Vermicomposting process resulted in a significant increase in nitrogen levels in majority of the beds (Table 3).

\section{ACCEPTED MANUSCRIPT 8}




\section{Phosphorous Levels Various Beds Prior to and After Composting Process}

Analysis of Variance results indicated that, the effects of the raw materials on phosphorous concentrations prior to and post - composting process were significant at the probability 0.001 level. Results of the comparison of the means showed that before Vermicomposting process, the highest and the lowest phosphorous concentrations were seen in the pomegranate peel and the sheep manure + spent mushroom compost + corn beds $(0.02 \mathrm{~g} / \mathrm{kg}$ and $0.01 \mathrm{~g} / \mathrm{kg})$, respectively (Table 4). Subsequent to Vermicomposting, the highest and the lowest Phosphorous levels were seen in the spent mushroom compost + sugar beet pulp + pomegranate peel and the sheep manure + spent mushroom compost + corn beds $(1.88 \mathrm{~g} / \mathrm{kg}$ and

$0.02 \mathrm{~g} / \mathrm{kg}$, respectively). According to the T-test results, Vermicomposting of culture beds led to a significant increase in Phosphorous concentrations in the majority of the beds (Table 4).

\section{Potassium Level in Various Beds Before and After the Vermicomposting Process}

The results of the analysis of variance revealed that the effects of the raw materials on the Potassium concentrations before and after Vermicomposting were significant at the 0.001 probability level. Comparison of the mean Potassium concentration showed the highest and the lowest Potassium concentration levels before Vermicomposting were in the sheep manure + corn and the sheep manure + pomegranate peel + sugar beet pulp beds $(11.37 \mathrm{~g} / \mathrm{kg}$ and $1.09 \mathrm{~g} / \mathrm{kg})$, respectively. Following the Vermicomposting also the highest and the lowest Potassium levels 
were observed in the sheep manure + pomegranate peel + spent mushroom compost and the pomegranate peel + sawdust beds $(17.38 \mathrm{~g} / \mathrm{kg}$ and $2.40 \mathrm{~g} / \mathrm{kg})$, respectively. Based on the T-test results, Vermicomposting of the culture beds led to a significant increase in Potassium level in the majority of the beds (Table 5).

\section{DISCUSSION}

Excessive salinity of Vermicompost can cause toxicity of plants, and its effect on plant species depends on the tolerance threshold and resistance of plants to salinity (Mengel et al., 2001). The harmless level of the EC in the Vermicompost should be about $2 \mathrm{dS} / \mathrm{m}$ or less (Hoekstra et al., 2002; Ofosu-Budu et al., 2010). Based on our results, the Vermicompost samples had lower salinity levels than the raw materials, as before the Vermicomposting process, the salinity levels in different treatments were between 2.45-11.52 $\mathrm{dS} / \mathrm{m}$ and after this process they were between $0.98-5.51 \mathrm{dS} / \mathrm{m}$. Overall, in the sheep manure + pomegranate peel, sheep manure + pomegranate peel + corn, pomegranate + sawdust, pomegranate peel + corn, pomegranate peel + sugar beet pulp and pomegranate peel alone, compared with other treatments, the salinity level was reduced more and was less that $2 \mathrm{dS} / \mathrm{m}$. the reason for this finding might be attributed to the easier leaching in Vermicompost and to a lesser degree of the consumption and accumulation of ions in the worm biomass. Considering the results, it can be seen that the pomegranate peel had a low EC and in combination with other substances such as sheep manure which has a high EC, has led to reduced salinity level in this bed.

\section{ACCEPTED MANUSCRIPT 10}




\section{ACCEPTED MANUSCRIPT}

The results of the present study are in agreement with those of Alikhani et al. (2011) and Tajbakhsh et al. (2008). The $\mathrm{pH}$ level too, is one of the indices for assessing the Vermicompost quality. Increased level of $\mathrm{pH}$ during Vermicomposting process can be due to increased content of mineral Nitrogen in the primary substrate. Regarding the short period of decomposing larger molecules like proteins, amino acids and fats, the release of their Nitrogen content as ammonia volatilization during the Vermicomposting process led to increased $\mathrm{pH}$ in these beds (Sodaei et al., 2007). In this regard, our results are in agreement with those of Sodaei et al. (2007) and Richard et al. (2009).

The results of the research indicate that the Vermicomposting process causes increased level of nutrients. Increased level of Nitrogen content of Vermicompost depends on the primary level of Nitrogen in the raw materials of the primary bed and also the degree of decomposition of such compounds during the Vermicomposting process. Loss of organic Carbon, decreased $\mathrm{pH}$, mineralization of organic substances containing protein and ammonia Nitrogen to Nitrates might be the reasons for the increased levels of Nitrogen in the Vermicompost (Pramanik et al., 2007; Contreras-Ramos et al., 2005; Amlinger et al., 2003). Additionally such factors like mucus secretion, Nitrogen containing substances, growth stimulating hormones and enzymes secreted by the earthworms are effective on the Nitrogen level of the final bed (Tripathi and Bhardwaj, 2004).

Earthworms also, through increasing mineralization of Nitrogen, highly influences modification of Nitrogen in fertilizers such that mineral Nitrogen may cause retention of the Nitrate form (Atiyeh et al., 2000). The results of the present study are in agreement with those of Warma and Anglopez (2002) and Suthar (2006). Suthar (2006) stated that the Vermicomposting 


\section{ACCEPTED MANUSCRIPT}

process caused significant increase of the total Nitrogen level in all the studied treatments. Among the reasons for increased level of Phosphorous in the Samples, carbon loss as $\mathrm{CO}_{2}$ gas and decreased volume of beds can be mentioned, since Phosphorous is not lost through the leaching and sublimation forms (Hashemi Majd, 2008).

Earthworms, through the Vermicomposting process by changing the insoluble phosphorous to the soluble form via the Phosphatase enzyme present in their stomachs can make Phosphorous more accessible to the plants. The main reason for the increased Phosphorous during the Vermicomposting process has been mentioned to be the presence of alkaline Phosphatase enzymes in the stool of the earthworms (Ghosh et al., 1999; Bayon and Binet, 2006). The difference in the level of Phosphorous concentration among the beds can be due to the time of performing the process, quality of the materials used by the worms, conditions of experiment, etc. The results of the present study are in agreement of Elvira et al. (1998), Hartenstein and Hartestein (1981), and Ndegwa and Thompson (2000). On the other hand, increased Potassium level in Vermicompost, indicate increase rate of mineralization of organic compounds containing Potassium and also other elements due to enzymatic and bacterial activities in the earthworm's digestive system (Garg et al., 2006). The presence of a rich microflora in the earthworm's intestine, has been mentioned to be an important factor contributing to increased Potassium level in the Vermicomposting process (Pramanik et al., 2007).

\section{CONCLUSIONS}




\section{ACCEPTED MANUSCRIPT}

Organic beds and various Wastes are used for producing Vermicompost, therefore, evaluation of the beds and selection of the best combination of the organic wastes for the purpose of increasing the amount of nutritional elements and also obtaining good quality for application as organic fertilizer is of utmost importance. Evidently, nutritional value of the produced Vermicompost depends, to a great degree, on the type and nature of the raw materials used, thus, an appropriate source of food for the earthworm. The most suitable percentage of mixture of nutritional materials can play an important role in the speed of growth, multiplication and nutrition of the worm and finally lead to production of a high quality Vermicompost. Since the process of Vermicomposting lead to decreased EC and increased level of nutrient elements such as Phosphorous, Potassium and Nitrogen in the studied materials, employment of this process for the purpose of improving chemical characteristics of the agricultural wastes for their conversion into a fertilizer rich in nutrient elements can be recommended. This can have a considerable effect on vegetative growth and regenerative of different plants. 


\section{REFERENCES}

Alidadi, H., Jaolie, F., Kamali, A., Solymani, S. 2007. Survey and choice of appropriate bed for preparing vermicompost from animal wastes. 9th National Conference on Environmental Health, Esfahan University of Medical Science.

Alikhani, H., Yakhchali, B., Mohammadi, L. 2011. Comparing Physiochemichal Properties of common Compost and Vermi-compost. Iranian Biology Journal, 6: 925-934.

Amlinger, F., Gotz, B., Dreher, P., Geszti, J., Weissteiner, C. 2003. Nitrogen in biowaste and yard waste compost: Dynamics of mobilization and availability. European Journal of Soil Biology, 39: 107-116.

Atiyeh, R. M., Dominguez, J., Subler, S., Edwards, C. A. 2000. Change in biochemical properties of cow manure during processing by earthworms (Eisenia anderi, Bouche') and effects on seedling growth. Pedobiologia, 44: 709-724.

Atiyeh, R. M., lee, S., Edwards, C. A., Arancon, N. Q., Metzger, J. D. 2002. The influences of humic acids derived from earthworm processed organic wastes on plant growth. Bioresource Technology, V-84: 7-14.

Bayon, L. R. C., Binet, F. 2006. Earthworm changes the distribution and availability of phosphorous in organic substrates. Soil Biology and Biochemistry, 38: 235-246.

Chattopadhyay, G. N. 2012. Use of vermicomposting biotechnology for recycling organic wastes in agriculture. International Journal of Recycling of Organic Waste, 1: 8-15. 


\section{ACCEPTED MANUSCRIPT}

Contreras-Ramos, S. M., Escamilla-Silva, E. M., Dendooven, L. 2005. Vermicomposting of biosolids with cow manure and oat straw. Biology and Fertility of Soils, 41: 190-198.

Elvira, C., Sampedro, L., Benitez, E., Nogales, R. 1998. Vermicomposting of sludges from paper mill and dairy industries with Eisenia andrei: A pilot scale study. Bioresource Technology, 63: 205-211.

Federico, A., Miceli, G., Santiago-Borraz, J., Molina, J. A. M., Nafate, C. C., Archila, M. A., Llaven, M. A. O., Rosales, R. R., Dendooven, L. 2007. Vermicompost as a soil supplement to improve growth, yield and fruit quality of tomato (Lycopersicum esculentum). Bioresource Technology, 98: 2781-2786.

Garg, P., Gupta, A., Satya, S. 2006. Vermicomposting of different type of waste using Eisenia foetida: A Comparative study. Bioresource Technology, 97: 391-395.

Ghaisari, S., Danesh, S. H., Abedini targhabe, J. 2009. Potential Usage of Vermi-compost Production Process for Recycling Vegetable Wastages. Agricultural and Natural Sources Science Journal, 2: 9.

Ghosh, M., Chattopadhyay, G. N., Baral, K. 1999. Transformation of phosphorus during vermicomposting. Bioresource Technology, 69:149-154.

Hartenstein, R., Hartenstein, F. 1981. Physicochemical Changes Effected in Activated Sludge by the Earthworm Eisenia Fetida. Journal of Environmental Quality, 10: 377-382.

Hashemi majd, K. 2008. Convertion Urban Sewage Lair to Vermi-compost by Using Native Soil Worms. Agriculture research: water, soil and plant in agriculture, 2: 35-44 


\section{ACCEPTED MANUSCRIPT}

Hoekstra, N. J., Bosker, T., Lantinga, E. A. 2002. Effects of cattle dung from farms with different feeding strategies on germination and initial root growth of cress (Lepidium sativum L.). Agriculture, Ecosystems \& Environment, 93: 189-196.

Khalfi, M., Ghanavi, Z., Rezazade, S. 2005. Comparison of chemical quality of compost and vermicompost produced from sugar beet waste. 7th National Conference on Environmental Health, Shahrekurd University of Medical Science.

Maboeta, M. S., Van Rensburg, L. 2003. Vermicomposting of industrially produced wood chips and sewage sludge utilizing Eisenia fetida. Ecotoxicology and Environmental safety, 56: 265-270.

Manna, M. C., Ghosh, J. S., Anharya, C. L. 2003. Comparative efficacy of three epigeic earthworms under different deciduous forest litters decomposition. Bioresource Technology, V-88- 3: 197-206.

Mengel, K., Kirkby, E.A., Kosegarten, H., Appel, T. 2001. Principles of Plant Nutrition. Fifthth edition. The Netherlands: Kluwer Academic Publishers.

Ndegwa, P. M., Thompson, S. A. 2000. Effects of C-to-N ratio on vermicomposting of biosolids. Bioresource Technology, 75: 7-12.

Ofosu-Budu, G. K., Hogarh, J. N., Fobil, J. N., Quaye, A., Danso, S. K. A., Carboo, D. 2010. Harmonizing procedures for the evaluation of compost maturity in two compost types in Ghana. Resources, Conservation and Recycling, 54: 205-209.

Parvaresh, A., Movahedian, A. H., Hamidian, L. 2005. Survey of chemical quality and fertilizer values of vermicompost prepared from municipal wastewater sludge in Esfahan. 7th 


\section{ACCEPTED MANUSCRIPT}

National Conference on Environmental Health, Shahrekurd University of Medical Science and health services.

Petmuenwai, N. 2013. Using Chicken Manure in Vermicompost to Manage Different AgroIndustrial Wastes. International Journal of Environmental and Rural Development (IJERD), 4-1: 69-74.

Pramanik, P., Ghosh, G. K., Ghosal, P. K., Banik, P. 2007. Changes in organic-C, N, P and K and enzyme activities in vermicompost of biodegradable organic waste under liming and microbial inoculants. Bioresource Technology, 98: 2485-2494.

Richard, T., Trautmann, N., Krasny, M., Fredenburg, S., Stuart, C. 2009. Cornell Composting, Cornell Waste Management Institute. Available from: http://compost.css.Cornell.edu/Composti ng _ homepage.html.

Sharma, S., Pradhan, K., Satya, S., Vasudevan, P. 2005. Potentially of Earthworn for Management and in Other Uses-A Review. American Science.

Sherman, R. 2003. Raising Earthworn Successfully. North Carolina Cooperative Extension Service.

Sodaei, M. S., Aliasgharzadeh, N., Oustan, S. H. 2007. Mineralization kinetic of nitrogen in an attended soil by compost, vermicompost and animal manure. Journal of Science and Technology of Agriculture and Natural Resources, 11: 405- 414.

Suthar, S. 2006. Potential utilization of guar gum industrial waste in vermicompost production. Bioresource Technology, 97: 2474-2477.

Tajbakhsh, J., Abdoli, M. A., Mohammadi Goltapeh, E., Alahdadi, I., Malakouti, M. J. 2008. Trend of physico-chemical properties change in recycling spent mushroom compost 


\section{ACCEPTED MANUSCRIPT}

through vermicomposting by epigeic earthworms Eisenia foetida and E. andrei. Journal of Agricultural Technology, 4: 185-198.

Tognetti, C. F., laos, M. J., Mazzarino Hernandez, M. T. 2005. Composting VS. Vermicomposting: A comparison of end product quality. Compost science utilization, V13: 6-13.

Tohidinejad, A., Madani, H., Jenabi, M. 2011. Organic Fertilizer and Vermi-compost Production (useful step in constant agriculture). First Edition. Shahid Bahounar university (Kerman) publication: 152 .

Tripathi, G., Bhardwaj, P. 2004. Comparative studies on biomass production, life cycles and composting efficiency of Eisenia fetida (Savigny) and Lampito mauritii (Kinberg). Bioresource Technology, 92: 275-283.

Warma, P. R., Anglopez, M. J. 2002. The chemical properties of vermicompost derived from different feed stocks. In: Proc Intl Composting and Compost Sci Simposium, Columbus, Ohio, CD Rom.

Yousefi, Z., Waaezzade, M., Amoie, A. 2008. Composting capability of Waste by earth worms in Mazandaran. 10th National Conference on Environmental Health, Hamadan University of Medical Science. 


\section{ACCEPTED MANUSCRIPT}

TABLE 1. Comparison of the EC (dS/m) of different beds (before and after vermi-composting)

\begin{tabular}{|c|c|c|c|}
\hline Bed & $\begin{array}{l}\text { Before } \\
\text { vermi- } \\
\text { compost } \\
\text { process }\end{array}$ & $\begin{array}{l}\text { After vermi- } \\
\text { compost } \\
\text { process }\end{array}$ & $\begin{array}{l}\text { Effect of vermi- } \\
\text { compost treatment }\end{array}$ \\
\hline $\mathrm{SM}+\mathrm{PP}$ & $2 / 45^{1 \mathrm{~A}}$ & $1 / 11^{\mathrm{ij} B}$ & $\mathrm{P}<0.024$ \\
\hline SM & $8 / 86^{\mathrm{cA}}$ & $4 / 22^{\mathrm{cdB}}$ & $\mathrm{P}<0.002$ \\
\hline $\mathrm{SM}+\mathrm{SMC}+\mathrm{C}$ & $6 / 35^{\text {ef } A}$ & $4 / 77^{\mathrm{bB}}$ & $\mathrm{P}<0.002$ \\
\hline $\mathrm{SM}+\mathrm{SMC}+\mathrm{SBP}$ & $3 / 90^{\mathrm{j} A}$ & $2 / 84^{\mathrm{fg} \mathrm{B}}$ & $\mathrm{P}<0.009$ \\
\hline $\mathrm{SM}+\mathrm{PP}+\mathrm{SMC}$ & $7 / 80^{\mathrm{dA}}$ & $4 / 10^{\text {cde } B}$ & $\mathrm{P}<0.009$ \\
\hline $\mathrm{SM}+\mathrm{PP}+\mathrm{SBP}$ & $5 / 56^{\mathrm{gA}}$ & $3 / 71^{\mathrm{e} B}$ & $\mathrm{P}<0.009$ \\
\hline $\mathrm{PP}+\mathrm{SMC}+\mathrm{C}$ & $6 / 28^{f A}$ & $2 / 80^{\text {fg B }}$ & $\mathrm{P}<0.001$ \\
\hline SMC + SBP & $3 / 77^{\mathrm{j} A}$ & $3 / 25^{\mathrm{fA}}$ & $\mathrm{P}<0.344$ \\
\hline $\mathrm{SM}+\mathrm{PP}+\mathrm{SMC}+\mathrm{C}$ & $9 / 39^{\mathrm{bA}}$ & $5 / 51^{\text {a B }}$ & $\mathrm{P}<0.003$ \\
\hline $\mathrm{PP}+\mathrm{S}$ & $11 / 52^{\mathrm{a} A}$ & $1 / 26^{\text {hij B }}$ & $\mathrm{P}<0.001$ \\
\hline $\mathrm{PP}$ & $5 / 70^{\mathrm{gA}}$ & $0 / 98^{\mathrm{j} B}$ & $\mathrm{P}<0.001$ \\
\hline $\mathrm{PP}+\mathrm{C}$ & $3 / 09^{\mathrm{kA}}$ & $1 / 14^{\mathrm{ij} B}$ & $\mathrm{P}<0.001$ \\
\hline $\mathrm{SMC}+\mathrm{C}$ & $4 / 33^{\mathrm{j} A}$ & $3 / 24^{\mathrm{fB}}$ & $\mathrm{P}<0.001$ \\
\hline $\mathrm{SM}+\mathrm{SMC}$ & $9 / 57^{\mathrm{bA}}$ & $4 / 68^{\mathrm{bB}}$ & $\mathrm{P}<0.001$ \\
\hline $\mathrm{SM}+\mathrm{PP}+\mathrm{SMC}+\mathrm{SBP}$ & $5 / 70^{\mathrm{g} A}$ & $4 / 48^{\mathrm{bc} \mathrm{B}}$ & $\mathrm{P}<0.031$ \\
\hline $\mathrm{SM}+\mathrm{PP}+\mathrm{C}$ & $6 / 68^{\mathrm{e} A}$ & $1 / 66^{\mathrm{h} B}$ & $\mathrm{P}<0.001$ \\
\hline
\end{tabular}




\section{ACCEPTED MANUSCRIPT}

\begin{tabular}{|l|l|l|l|}
\hline $\mathrm{SM}+\mathrm{S}$ & $8 / 86^{\mathrm{cA}}$ & $3 / 85^{\mathrm{dcB}}$ & $\mathrm{P}<0.002$ \\
\hline $\mathrm{PP}+\mathrm{SBP}$ & $3 / 21^{\mathrm{kA}}$ & $1 / 48^{\mathrm{hi}}$ & $\mathrm{P}<0.002$ \\
\hline $\mathrm{PP}+\mathrm{SMC}$ & $3 / 21^{\mathrm{kA}}$ & $2 / 40^{\mathrm{gA}}$ & $\mathrm{P}<0.061$ \\
\hline $\mathrm{SMC}+\mathrm{SBP}+\mathrm{PP}$ & $5 / 04^{\mathrm{hA}}$ & $2 / 53^{\mathrm{gB}}$ & $\mathrm{P}<0.016$ \\
\hline $\mathrm{SM}+\mathrm{SBP}$ & $9 / 40^{\mathrm{bA}}$ & $2 / 62^{\mathrm{gB}}$ & $\mathrm{P}<0.002$ \\
\hline $\mathrm{SM}+\mathrm{C}$ & $11 / 52^{\mathrm{aA}}$ & $4 / 70^{\mathrm{bB}}$ & $\mathrm{P}<0.001$ \\
\hline SMC & $5 / 19^{\mathrm{hA}}$ & $2 / 76^{\mathrm{gB}}$ & $\mathrm{P}<0.003$ \\
\hline
\end{tabular}

Values in each column followed by the equal low case letters are not significantly different at the 5\% probability level according to Duncan's Multiple Range Test (effect of bed). Values in each column followed by the equal capital letters are not significantly different at the $5 \%$ probability level according to Duncan's Multiple Range Test (effect of vermi-composting). Sheep manure (SM), Pomegranate peel (PP), Spent mushroom compost (SMC), Corn (C), Sugar beet pulp (SBP), Sawdust (S). 
TABLE 2. Comparison of the $\mathrm{pH}$ in different beds (before and after vermi-composting)

\begin{tabular}{|c|c|c|c|}
\hline Bed & $\begin{array}{l}\text { Before vermi- } \\
\text { compost process }\end{array}$ & $\begin{array}{l}\text { After vermi- } \\
\text { compost process }\end{array}$ & $\begin{array}{l}\text { Effect of vermi- } \\
\text { compost treatment }\end{array}$ \\
\hline $\mathrm{SM}+\mathrm{PP}$ & $5 / 02^{\text {hi B }}$ & $7 / 85^{\mathrm{a} A}$ & $\mathrm{P}<0.002$ \\
\hline SM & $7 / 83^{\mathrm{a} A}$ & $7 / 90^{\mathrm{a} A}$ & $\mathrm{P}<0.599$ \\
\hline $\mathrm{SM}+\mathrm{SMC}+\mathrm{C}$ & $7 / 22^{\mathrm{cdB}}$ & $7 / 59^{\mathrm{b} A}$ & $\mathrm{P}<0.001$ \\
\hline $\mathrm{SM}+\mathrm{SMC}+\mathrm{SBP}$ & $4 / 82^{i B}$ & $7 / 40^{\mathrm{bcd} A}$ & $\mathrm{P}<0.001$ \\
\hline $\mathrm{SM}+\mathrm{PP}+\mathrm{SMC}$ & $7 / 21^{\mathrm{cd} A}$ & $7 / 54^{\mathrm{bc} \mathrm{A}}$ & $\mathrm{P}<0.060$ \\
\hline $\mathrm{SM}+\mathrm{PP}+\mathrm{SBP}$ & $7 / 97^{\mathrm{a} A}$ & $7 / 55^{\mathrm{bcB}}$ & $\mathrm{P}<0.002$ \\
\hline $\mathrm{PP}+\mathrm{SMC}+\mathrm{C}$ & $6 / 95^{\mathrm{efg} B}$ & $7 / 32^{\mathrm{cd} A}$ & $\mathrm{P}<0.002$ \\
\hline $\mathrm{SMC}+\mathrm{SBP}$ & $6 / 85^{\mathrm{fg} B}$ & $7 / 57^{\mathrm{b} A}$ & $\mathrm{P}<0.004$ \\
\hline $\mathrm{SM}+\mathrm{PP}+\mathrm{SMC}+\mathrm{C}$ & $7 / 02^{\operatorname{def} B}$ & $7 / 40^{\mathrm{bcd} A}$ & $\mathrm{P}<0.001$ \\
\hline$P P+S$ & $7 / 41^{\text {bc B }}$ & $7 / 56^{\mathrm{bA}}$ & $\mathrm{P}<0.023$ \\
\hline PP & $7 / 19^{\text {cde A }}$ & $7 / 58^{\mathrm{b} A}$ & $\mathrm{P}<0.392$ \\
\hline $\mathrm{PP}+\mathrm{C}$ & $3 / 67^{\mathrm{kB}}$ & $7 / 60^{\mathrm{b} A}$ & $\mathrm{P}<0.001$ \\
\hline $\mathrm{SMC}+\mathrm{C}$ & $7 / 34^{\mathrm{bcA}}$ & $7 / 29^{\mathrm{d} A}$ & $\mathrm{P}<0.491$ \\
\hline $\mathrm{SM}+\mathrm{SMC}$ & $7 / 20^{\text {cde A }}$ & $7 / 36^{\mathrm{bcd} A}$ & $\mathrm{P}<0.383$ \\
\hline $\mathrm{SM}+\mathrm{PP}+\mathrm{SMC}+\mathrm{SBP}$ & $7 / 55^{\mathrm{b} A}$ & $7 / 40^{\mathrm{bcd} A}$ & $\mathrm{P}<0.409$ \\
\hline $\mathrm{SM}+\mathrm{PP}+\mathrm{C}$ & $7 / 19^{\text {cde A }}$ & $7 / 43^{\mathrm{bcd} A}$ & $\mathrm{P}<0.335$ \\
\hline $\mathrm{SM}+\mathrm{S}$ & $7 / 56^{\mathrm{b} A}$ & $7 / 92^{\mathrm{aA}}$ & $\mathrm{P}<0.097$ \\
\hline
\end{tabular}




\section{ACCEPTED MANUSCRIPT}

\begin{tabular}{|l|l|l|l|}
\hline PP + SBP & $4 / 47^{\mathrm{jB}}$ & $7 / 98^{\mathrm{a} A}$ & $\mathrm{P}<0.002$ \\
\hline $\mathrm{PP}+$ SMC & $6 / 74^{\mathrm{gB}}$ & $7 / 37^{\mathrm{bcdA}}$ & $\mathrm{P}<0.046$ \\
\hline SMC + SBP+ PP & $7 / 03^{\text {def B }}$ & $7 / 56^{\mathrm{bA}}$ & $\mathrm{P}<0.007$ \\
\hline SM+ SBP & $5 / 24^{\mathrm{hB}}$ & $7 / 85^{\mathrm{aA}}$ & $\mathrm{P}<0.001$ \\
\hline SM+ C & $7 / 03^{\text {detB }}$ & $7 / 92^{\mathrm{aA}}$ & $\mathrm{P}<0.002$ \\
\hline SMC & $7 / 05^{\text {def A }}$ & $7 / 22^{\mathrm{dA}}$ & $\mathrm{P}<0.246$ \\
\hline
\end{tabular}

Values in each column followed by the equal low case letters are not significantly different at the

5\% probability level according to Duncan's Multiple Range Test (effect of bed). Values in each column followed by the equal capital letters are not significantly different at the $5 \%$ probability level according to Duncan's Multiple Range Test (effect of vermi-composting). Sheep manure (SM), Pomegranate peel (PP), Spent mushroom compost (SMC), Corn (C), Sugar beet pulp (SBP), Sawdust (S). 
TABLE 3. Comparison of the $\mathrm{N}(\%)$ in different beds (before and after vermin-compost process)

\begin{tabular}{|c|c|c|c|}
\hline Bed & $\begin{array}{l}\text { Before vermi- } \\
\text { compost } \\
\text { process }\end{array}$ & $\begin{array}{l}\text { After vermi-compost } \\
\text { process }\end{array}$ & $\begin{array}{l}\text { Effect of vermi- } \\
\text { compost treatment }\end{array}$ \\
\hline $\mathrm{SM}+\mathrm{PP}$ & $1 / 33^{\mathrm{dB}}$ & $1 / 89^{\text {cde A }}$ & $\mathrm{P}<0.001$ \\
\hline SM & $1 / 26^{\mathrm{e} B}$ & $1 / 94^{\mathrm{bcd} A}$ & $\mathrm{P}<0.002$ \\
\hline $\mathrm{SM}+\mathrm{SMC}+\mathrm{C}$ & $1 / 77^{\mathrm{a} A}$ & $1 / 79^{\operatorname{def} A}$ & $\mathrm{P}<0.835$ \\
\hline $\mathrm{SM}+\mathrm{SMC}+\mathrm{SBP}$ & $0 / 86^{1 \mathrm{~B}}$ & $1 / 74^{\text {efg A }}$ & $\mathrm{P}<0.001$ \\
\hline $\mathrm{SM}+\mathrm{PP}+\mathrm{SMC}$ & $0 / 90^{\mathrm{jkl} \mathrm{B}}$ & $1 / 57^{\text {hij A }}$ & $\mathrm{P}<0.001$ \\
\hline $\mathrm{SM}+\mathrm{PP}+\mathrm{SBP}$ & $1 / 71^{\mathrm{bB}}$ & $2 / 02^{\mathrm{abc} A}$ & $\mathrm{P}<0.011$ \\
\hline $\mathrm{PP}+\mathrm{SMC}+\mathrm{C}$ & $1 / 00^{\text {hi B }}$ & $1 / 52^{\mathrm{ij} \mathrm{A}}$ & $\mathrm{P}<0.015$ \\
\hline $\mathrm{SMC}+\mathrm{SBP}$ & $1 / 07^{\text {fg A }}$ & $1 / 23^{\mathrm{mA}}$ & $\mathrm{P}<0.120$ \\
\hline $\mathrm{SM}+\mathrm{PP}+\mathrm{SMC}+\mathrm{C}$ & $1 / 09^{\mathrm{fB}}$ & $1 / 81^{\operatorname{def} A}$ & $\mathrm{P}<0.001$ \\
\hline$P P+S$ & $0 / 95^{\mathrm{ij} B}$ & $1 / 86^{\text {de A }}$ & $\mathrm{P}<0.003$ \\
\hline $\mathrm{PP}$ & $1 / 03^{\text {gh B }}$ & $1 / 31^{\operatorname{lm} A}$ & $\mathrm{P}<0.001$ \\
\hline $\mathrm{PP}+\mathrm{C}$ & $1 / 40^{\mathrm{c} B}$ & $1 / 69^{\text {fgh } A}$ & $\mathrm{P}<0.010$ \\
\hline $\mathrm{SMC}+\mathrm{C}$ & $0 / 89^{\mathrm{klB}}$ & $1 / 69^{\text {fgh } A}$ & $\mathrm{P}<0.003$ \\
\hline $\mathrm{SM}+\mathrm{SMC}$ & $1 / 07^{\text {fg B }}$ & $1 / 62^{\text {ghi A }}$ & $\mathrm{P}<0.010$ \\
\hline $\mathrm{SM}+\mathrm{PP}+\mathrm{SMC}+\mathrm{SBP}$ & $1 / 00^{\mathrm{hi} \mathrm{B}}$ & $1 / 67^{\text {fgh } A}$ & $\mathrm{P}<0.006$ \\
\hline $\mathrm{SM}+\mathrm{PP}+\mathrm{C}$ & $0 / 99^{\text {hi B }}$ & $2 / 07^{\mathrm{ab} \mathrm{A}}$ & $\mathrm{P}<0.001$ \\
\hline
\end{tabular}




\section{ACCEPTED MANUSCRIPT}

\begin{tabular}{|l|l|l|l|}
\hline $\mathrm{SM}+\mathrm{S}$ & $0 / 98^{\mathrm{hi} \mathrm{B}}$ & $1 / 60^{\text {ghi A }}$ & $\mathrm{P}<0.001$ \\
\hline $\mathrm{PP}+\mathrm{SBP}$ & $1 / 29^{\mathrm{de} \mathrm{B}}$ & $1 / 48^{\mathrm{jik} A}$ & $\mathrm{P}<0.022$ \\
\hline $\mathrm{PP}+\mathrm{SMC}$ & $0 / 95^{\mathrm{ijk} A}$ & $1 / 35^{\mathrm{klm} \mathrm{A}}$ & $\mathrm{P}<0.061$ \\
\hline $\mathrm{SMC}+\mathrm{SBP}+\mathrm{PP}$ & $0 / 74^{\mathrm{mB}}$ & $1 / 58^{\mathrm{hiA}}$ & $\mathrm{P}<0.008$ \\
\hline $\mathrm{SM}+\mathrm{SBP}$ & $1 / 43^{\mathrm{cB}}$ & $2 / 10^{\mathrm{a} A}$ & $\mathrm{P}<0.013$ \\
\hline $\mathrm{SM}+\mathrm{C}$ & $1 / 26^{\mathrm{cB}}$ & $2 / 07^{\mathrm{ab} \mathrm{A}}$ & $\mathrm{P}<0.010$ \\
\hline $\mathrm{SMC}$ & $0 / 76^{\mathrm{mB}}$ & $1 / 42^{\mathrm{jkl} \mathrm{A}}$ & $\mathrm{P}<0.005$ \\
\hline
\end{tabular}

Values in each column followed by the equal low case letters are not significantly different at the 5\% probability level according to Duncan's Multiple Range Test (effect of bed) Values in each column followed by the equal capital letters are not significantly different at the $5 \%$ probability level according to Duncan's Multiple Range Test (effect of vermi-composting). Sheep manure (SM), Pomegranate peel (PP), Spent mushroom compost (SMC), Corn (C), Sugar beet pulp (SBP), Sawdust (S). 
TABLE 4. Compare $\mathrm{P}$ ( $\mathrm{g} / \mathrm{kg}$ ) in different beds (before and after vermin-compost process)

\begin{tabular}{|c|c|c|c|}
\hline Bed & $\begin{array}{l}\text { Before vermi- } \\
\text { compost process }\end{array}$ & $\begin{array}{l}\text { After vermi- } \\
\text { compost process }\end{array}$ & $\begin{array}{l}\text { Effect of vermi- } \\
\text { compost treatment }\end{array}$ \\
\hline $\mathrm{SM}+\mathrm{PP}$ & $0 / 05^{\mathrm{g} B}$ & $0 / 13^{\mathrm{mn} A}$ & $\mathrm{P}<0.001$ \\
\hline SM & $0 / 10^{\mathrm{dB}}$ & $0 / 42^{\mathrm{e} A}$ & $\mathrm{P}<0.001$ \\
\hline $\mathrm{SM}+\mathrm{SMC}+\mathrm{C}$ & $0 / 01^{1 \mathrm{~B}}$ & $0 / 02^{\mathrm{OA}}$ & $\mathrm{P}<0.009$ \\
\hline $\mathrm{SM}+\mathrm{SMC}+\mathrm{SBP}$ & $0 / 04^{\text {gh } B}$ & $0 / 28^{\text {hi A }}$ & $\mathrm{P}<0.002$ \\
\hline $\mathrm{SM}+\mathrm{PP}+\mathrm{SMC}$ & $0 / 04^{\text {gh B }}$ & $0 / 13^{\mathrm{mn} A}$ & $\mathrm{P}<0.017$ \\
\hline $\mathrm{SM}+\mathrm{PP}+\mathrm{SBP}$ & $0 / 10^{\mathrm{dB}}$ & $0 / 73^{\mathrm{cA}}$ & $\mathrm{P}<0.001$ \\
\hline $\mathrm{PP}+\mathrm{SMC}+\mathrm{C}$ & $0 / 07^{\mathrm{fB}}$ & $0 / 12^{\text {n }}$ & $\mathrm{P}<0.013$ \\
\hline $\mathrm{SMC}+\mathrm{SBP}$ & $0 / 04^{\text {gh B }}$ & $0 / 83^{\mathrm{bA}}$ & $\mathrm{P}<0.001$ \\
\hline $\mathrm{SM}+\mathrm{PP}+\mathrm{SMC}+\mathrm{C}$ & $0 / 03^{h \mathrm{~B}}$ & $0 / 21^{\mathrm{jk} A}$ & $\mathrm{P}<0.001$ \\
\hline $\mathrm{PP}+\mathrm{S}$ & $0 / 13^{\mathrm{c} A}$ & $0 / 18^{\mathrm{kIA}}$ & $\mathrm{P}<0.060$ \\
\hline $\mathrm{PP}$ & $0 / 020^{\mathrm{a} A}$ & $0 / 23^{j A}$ & $\mathrm{P}<0.184$ \\
\hline $\mathrm{PP}+\mathrm{C}$ & $0 / 18^{\mathrm{b} B}$ & $0 / 33^{g A}$ & $\mathrm{P}<0.012$ \\
\hline $\mathrm{SMC}+\mathrm{C}$ & $0 / 08^{\text {ef B }}$ & $0 / 37^{\mathrm{fA}}$ & $\mathrm{P}<0.001$ \\
\hline $\mathrm{SM}+\mathrm{SMC}$ & $0 / 07^{\mathrm{fB}}$ & $0 / 21^{\mathrm{jk} A}$ & $\mathrm{P}<0.036$ \\
\hline $\mathrm{SM}+\mathrm{PP}+\mathrm{SMC}+\mathrm{SBP}$ & $0 / 03^{\mathrm{hB}}$ & $0 / 23^{\mathrm{j} A}$ & $\mathrm{P}<0.005$ \\
\hline $\mathrm{SM}+\mathrm{PP}+\mathrm{C}$ & $0 / 11^{\mathrm{dB}}$ & $0 / 32^{g A}$ & $\mathrm{P}<0.045$ \\
\hline $\mathrm{SM}+\mathrm{S}$ & $0 / 11^{\mathrm{d} A}$ & $0 / 46^{\mathrm{dA}}$ & $\mathrm{P}<0.002$ \\
\hline
\end{tabular}




\section{ACCEPTED MANUSCRIPT}

\begin{tabular}{|l|l|l|l|}
\hline PP + SBP & $0 / 16^{6 \mathrm{~B}}$ & $0 / 32^{\mathrm{gh} \mathrm{A}}$ & $\mathrm{P}<0.006$ \\
\hline PP+ SMC & $0 / 10^{\mathrm{dB}}$ & $0 / 25^{\mathrm{ijA}}$ & $\mathrm{P}<0.001$ \\
\hline SMC + SBP+ PP & $0 / 04^{\mathrm{gh} B}$ & $1 / 88^{\mathrm{aA}}$ & $\mathrm{P}<0.001$ \\
\hline SM+ SBP & $0 / 11^{\mathrm{dB}}$ & $0 / 86^{\mathrm{bA}}$ & $\mathrm{P}<0.001$ \\
\hline SM+C & $0 / 08^{\mathrm{efB}}$ & $0 / 16^{\operatorname{lmA}}$ & $\mathrm{P}<0.001$ \\
\hline SMC & $0 / 07^{\mathrm{fB}}$ & $0 / 10^{\mathrm{nA}}$ & $\mathrm{P}<0.036$ \\
\hline
\end{tabular}

Values in each column followed by the equal low case letters are not significantly different at the

5\% probability level according to Duncan's Multiple Range Test (effect of bed). Values in each column followed by the equal capital letters are not significantly different at the $5 \%$ probability level according to Duncan's Multiple Range Test (effect of vermi-composting). Sheep manure

(SM), Pomegranate peel (PP), Spent mushroom compost (SMC), Corn (C), Sugar beet pulp (SBP), Sawdust (S). 
TABLE 5. Compare $\mathrm{K}(\mathrm{g} / \mathrm{kg}$ ) in different beds (before and after vermin-compost process)

\begin{tabular}{|c|c|c|c|}
\hline Bed & $\begin{array}{l}\text { Before vermi- } \\
\text { compost } \\
\text { process }\end{array}$ & $\begin{array}{l}\text { After vermi- } \\
\text { compost process }\end{array}$ & $\begin{array}{l}\text { Effect of vermi- } \\
\text { compost treatment }\end{array}$ \\
\hline $\mathrm{SM}+\mathrm{PP}$ & $5 / 84^{\text {de B }}$ & $13 / 71^{\mathrm{bA}}$ & $\mathrm{P}<0.005$ \\
\hline SM & $4 / 57^{\mathrm{fB}}$ & $9 / 56^{\mathrm{e} A}$ & $\mathrm{P}<0.001$ \\
\hline $\mathrm{SM}+\mathrm{SMC}+\mathrm{C}$ & $9 / 07^{\text {bc B }}$ & $12 / 30^{\mathrm{c} A}$ & $\mathrm{P}<0.050$ \\
\hline $\mathrm{SM}+\mathrm{SMC}+\mathrm{SBP}$ & $5 / 37^{\text {ef } A}$ & $6 / 40^{\mathrm{fA}}$ & $\mathrm{P}<0.070$ \\
\hline $\mathrm{SM}+\mathrm{PP}+\mathrm{SMC}$ & $10 / 72^{\mathrm{a} B}$ & $17 / 38^{\mathrm{a} A}$ & $\mathrm{P}<0.021$ \\
\hline $\mathrm{SM}+\mathrm{PP}+\mathrm{SBP}$ & $1 / 09^{k B}$ & $9 / 50^{\mathrm{eA}}$ & $\mathrm{P}<0.001$ \\
\hline $\mathrm{PP}+\mathrm{SMC}+\mathrm{C}$ & $3 / 15^{\text {ghi B }}$ & $5 / 30^{\mathrm{gh} \mathrm{A}}$ & $\mathrm{P}<0.006$ \\
\hline $\mathrm{SMC}+\mathrm{SBP}$ & $3 / 62^{\mathrm{gA}}$ & $4 / 23^{\mathrm{ij} A}$ & $\mathrm{P}<0.122$ \\
\hline $\mathrm{SM}+\mathrm{PP}+\mathrm{SMC}+\mathrm{C}$ & $9 / 71^{\mathrm{bB}}$ & $12 / 30^{\mathrm{c} A}$ & $\mathrm{P}<0.001$ \\
\hline $\mathrm{PP}+\mathrm{S}$ & $2 / 12^{\mathrm{j} A}$ & $2 / 46^{1 A}$ & $\mathrm{P}<0.112$ \\
\hline PP & $2 / 90^{\mathrm{gj} B}$ & $5 / 58^{\mathrm{fg} A}$ & $\mathrm{P}<0.001$ \\
\hline $\mathrm{PP}+\mathrm{C}$ & $3 / 15^{\text {ghi B }}$ & $4 / 50^{\text {hi A }}$ & $\mathrm{P}<0.002$ \\
\hline $\mathrm{SMC}+\mathrm{C}$ & $3 / 29^{\text {gh B }}$ & $3 / 34^{\mathrm{jkl} A}$ & $\mathrm{P}<0.005$ \\
\hline SM + SMC & $6 / 62^{\mathrm{dB}}$ & $9 / 63^{\mathrm{e} A}$ & $\mathrm{P}<0.014$ \\
\hline $\mathrm{SM}+\mathrm{PP}+\mathrm{SMC}+\mathrm{SBP}$ & $8 / 40^{\mathrm{cB}}$ & $9 / 65^{\mathrm{e} A}$ & $\mathrm{P}<0.021$ \\
\hline $\mathrm{SM}+\mathrm{PP}+\mathrm{C}$ & $3 / 62^{g B}$ & $10 / 85^{\mathrm{dA}}$ & $\mathrm{P}<0.001$ \\
\hline
\end{tabular}




\begin{tabular}{|l|l|l|l|}
\hline $\mathrm{SM}+\mathrm{S}$ & $3 / 49^{\mathrm{gB}}$ & $9 / 72^{\mathrm{eA}}$ & $\mathrm{P}<0.001$ \\
\hline $\mathrm{PP}+\mathrm{SBP}$ & $2 / 11^{\mathrm{jB}}$ & $3 / 74^{\mathrm{ijk} A}$ & $\mathrm{P}<0.031$ \\
\hline $\mathrm{PP}+\mathrm{SMC}$ & $2 / 34^{\mathrm{hij} B}$ & $3 / 14^{\mathrm{klA}}$ & $\mathrm{P}<0.019$ \\
\hline SMC + SBP+ PP & $9 / 71^{\mathrm{bB}}$ & $11 / 83^{\mathrm{cA}}$ & $\mathrm{P}<0.043$ \\
\hline SM+ SBP & $2 / 21^{\mathrm{ijB}}$ & $6 / 03^{\mathrm{fg} A}$ & $\mathrm{P}<0.007$ \\
\hline $\mathrm{SM}+\mathrm{C}$ & $11 / 37^{\mathrm{a} A}$ & $16 / 47^{\mathrm{a} A}$ & $\mathrm{P}<0.049$ \\
\hline SMC & $2 / 51^{\mathrm{hij} B}$ & $4 / 16^{\mathrm{ijk} \mathrm{A}}$ & $\mathrm{P}<0.004$ \\
\hline
\end{tabular}

Values in each column followed by the equal low case letters are not significantly different at the 5\% probability level according to Duncan's Multiple Range Test (effect of bed). Values in each column followed by the equal capital letters are not significantly different at the $5 \%$ probability level according to Duncan's Multiple Range Test (effect of vermi-composting). Sheep manure (SM), Pomegranate peel (PP), Spent mushroom compost (SMC), Corn (C), Sugar beet pulp (SBP), Sawdust (S). 